\title{
Minder fra drengeårene på Skovgård og i Åbenrå
}

\author{
Af Troels Refslund Poulsen
}

Troels Refslund Poulsen er født 1904 som søn af gårdejer Marten Refslund Poulsen, der er kendt for sin indsats på mange felter $i$ det nationale arbejde. Troels Refslund Poulsen fortæller her om sine oplevelser fra de tidlige barndomsår på gården Skovgård ved Ảbenrå, om skolegang $\mathrm{i}$ preussisk skole, og om sine to drengeår i A benrå, før familien fandt blivende sted i Bovlund.

\section{Skovgård}

Det var forår på Åbenråegnen, sol og høj himmel med begyndende lunhed. På gården Skovgård, hvor mine forældre og vi søskende boede, luftedes der sengetøj $\mathrm{i}$ den store gårdsplads nord for stuehuset. Stuepigen ordnede dette og skulle samtidig passe på min lille eksistens, der samme skønne dag for første gang mærkede et bevidsthedsliv. Stuepigen loftede mig over stakittet, som omhegnede den runde plæne midt $\mathrm{i}$ gårdspladsen, og lod mig blive der for at lette sine forpligtelser med at passe på, at drengen ikke forsvandt. $\mathrm{Da}$ pigen kom ud med mere tøj, havde jeg begyndt at sparke på stakittet for at komme ud af mit indelukke. Hun sagde: "Pas på, at du ikke sparker snuden ud af dine træsko". Det er de første ord, jeg kan huske, der er blevet talt til mig.

En anden dag var der nogen, der tog mig ved hånden og gik med mig over $\mathrm{i}$ kostalden. Inden for døren så jeg en bred gang og oppe til højre en række store dyr, køer, der stod bundne. Det indså jeg, de måtte være, siden de stod $\mathrm{i}$ række. Deres gøren og laden lod mig også forstå, at de $\mathrm{i}$ lang tid havde været afskåret fra enhver naturlig oplevelse og deres initiativ ligeledes frataget dem, undtagen lige til at 
æde og så foretage den nødvendige afføring, og til den gik der så megen tid, så jeg syntes, det grænsede til det usømmelige.

Skovgård var et dejligt sted at vokse op i. Der var langt til naboer, en stor have, der spidsede til mellem trxerne $i$ sydøst, stuehus med veranda og en murstensbue over hver skorsten, sikkert udført for at vinden fra træerne ikke skulle slå ned.

Fra toften i syd kunne man se marker mellem skovene helt ned til Ảbenrå fjord, der lå dybest som et blåt bånd, og bagved $\mathrm{i}$ disen sydsiden af fjorden, også skovklædt, 7-8 km borte Hostrupskov og Feldstedskove.

Dagene gik. I den mørke tid kunne der komme enkelte snefnug. De tegnede sig som små hvide uldtotter, der langsomt dalede ned, let synlige gennem dagligstuevinduet mod den mørkere farve på verandaens træværk skråt overfor. I underbevidstheden lå, at far var derude og arbejdede et ubestemt sted. Han mærkede måske i dette nu enkelte snefnugs kildren på halsen, før de blev optøet af kropsvarmen. I kakkelovnen bag marieglasset glødede arneflammen, mere synligt nu, eftersom mørket faldt på. Der var nylig lagt brænde på, bøgeklov af egen hugst forarbejdet med økse og båndsav. Der var endnu saftrester tilbage $i$ træet, de viste sig, hvor savsnittet var foretaget. Væden trak ud under træets opvarmning, og under sagte syden dannedes der små bobler, der fordampede, når flammerne nærmede sig. Hyggeligt var der, mor hørtes et sted $i$ huset håndtere med lillesøster Else, dette søde, lidt utrolige vasen, der var kommet ind $\mathrm{i}$ vores tilværelse. Efter sigende skulle sygeplejersken have haft hende med $i$ sin kuffert. Forholdet syntes at have en lille grad af mystik; men den med kufferten godtoges under hensyn til ens daværende mangel på evner og kræfter til at gå dybere $\mathrm{i}$ sagen.

$P a ̊$ vestsiden af havens krumning gik en vej, der kun var lidt befærdet, den gik videre gennem Damms teglgård og endte ned ad bakken i Kolstrup og Åbenrå. Det var godt for en lille purk at gå på opdagelse i den store have. Far havde fået dammen ryddet og spenderet en bro med hvidt gelæender over til en lille $\varnothing$, der lå midt $i$. Ved en slags indvielse af den deltog fars og mors venner, Ingeborg, H. P. Hanssens datter, og Kresten Refslund Thomsen, den senere amtmand. De to var nyforlovede dengang.

En tidlig forårsdag havde jeg vovet mig ud af havelågen længst nede og ud på vejen. Sikken et dejligt syn. Det klare tøvand piblede 
ud af snedriverne, der havde lagt sig i l $x$ af hasselhegnene. Vandet piblede videre langs hjulsporene og ned $\mathrm{i}$ grefterne. I luften tonede små lærketriller, og over det hele en klar, men endnu bleg sol, der varslede vår.

Hver sondag formiddag gik far og mor de $3 \mathrm{~km}$ til frimenighedskirken i Åbenrå. Sommetider havde de "kiksdyr « med hjem til os, og så var søndagen reddet. Hvis de ingen »kiksdyr « havde med, sagde min to år xldre søster Karen: »Moa! - hvis do it ka' haus' et, ska do bae sej: »kiksdye - kiksdye« for hvert skridt, helt te do fåe dem køjt «.

Engang da samme søster Karen var blevet stor nok dertil, tog far og mor hende med til kirke. Hun kom hjem fuld af begejstring: »Oh - ha - Troels, do sku li' ha væt mæ - dx va manne folk - a såen køn musik - snae' som ve en karussell - å - vopti så stau di op oll sammel!«

Der var mange ting at tage vare på på gården. Efter høst damptærskeværket, vi kunne følge sceneriet fra legestuen. Presseren blev stillet op foran ladeporten, så halmen kunne presses ind, derefter kom det store kastel til tærskeværk, sidst kom det sorte noget mindre, men energisk udseende, lokomobil, og der lå en dynge kul, som lokomobilet skulle fodres med, før det hele kom til at løbe rundt. To sorte jernkugler svingede rundt om en lodret aksel oven på lokomobilet. De dannede regulator. Når farten blev sat ned p. gr. af overbelastning, sank kuglerne ned, bestemt af centrifugalkraften, og dermed lukkedes der mere op for dampspjxldet. Så var den normale fart på maskineriet der igen. To mænd bar de tunge sxkke med korn i langsomt tempo op forbi vort vindue og op på stuehusloftet. De krydsede hinandens gang, når de gik hen og tilbage. Ialt var der ca. 8 mand beskæftiget ved tærskeværket, et stort opbud for at fă arbejdet gjort i forhold til nu om dage med mejetxrskerne.

En dag var far ved at stille såmaskinen ind ovre ved den store lade. Det tog tid, og noget efter undrede vi børn os over, at der kom en masse små planter på stedet. De havde allesammen to kimblade som struttede ud til siden, så det har været kålroefrø, der var tabt.

Det skete, at far sendte en karl til Åbenrå med hestekøretøj for at forrette ærinder. Engang da karlen kørte hjem, var der nogle drenge, der hægtede sig fast bagi vognen - de troede han havde æeg med - og råbte til karlen på deres blanding af plattysk og dialekt: »Hæ do ei!k 


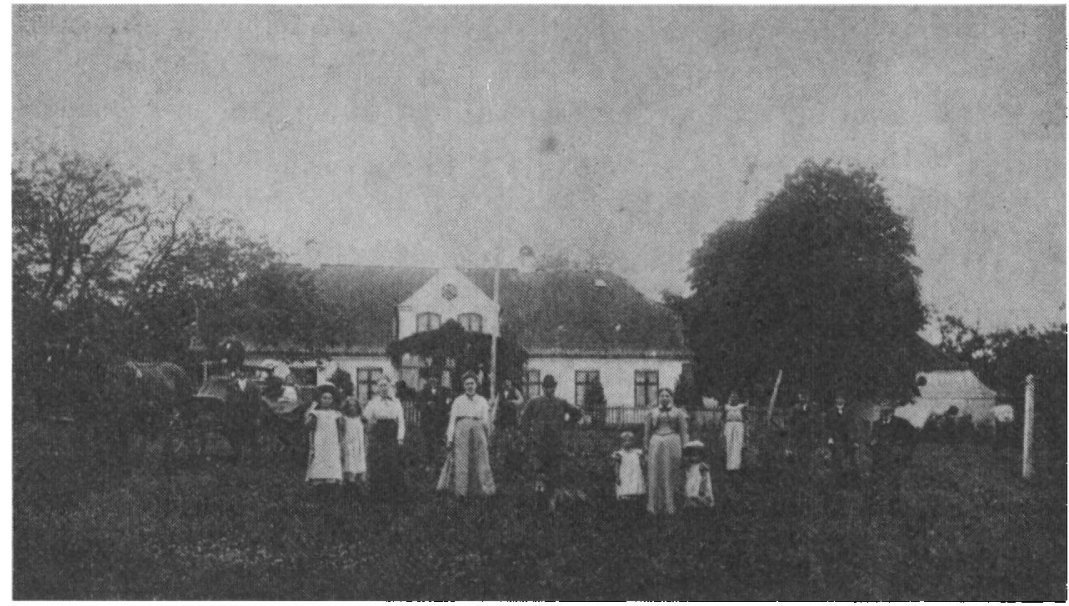

Skovgaird ved Abenrd var bygget $i$ 1840'erne af stenderdeputeret Cbr. Hansen Moller, der udviklede et monsterlandbrug dér. Gdrden ejedes 1906-12 af Marten Refslund Poulsen. Foto fra begyndelsen af drbundredet.

- „H $\boldsymbol{x}$ do ei? \& Karlen vendte sig irriteret om og råbte: $₫$ Hva hx $\boldsymbol{x}$ ei? \& - Til sidst måtte han true med pisken for at få dem til at slippe taget $i$ vognen.

På Skovgård fik vi somme tider besøg af min faster Margrethe og onkel Henrik Ravn fra Dons. Engang de *blev nat “, havde de deres søn, min fætter Kristian, med. Det var sjovt, og ved sengetid kom han $i$ en lille seng, der blev stillet op til ham inde hos os andre børn $i$ børneværelset, og nu gik børnesnakken, hvorunder vi hver ville hævde vor dialekt som den rigtige. Det var da et mærkeligt sprog vor halvfremmede fætter forte. Han sagde »a«, og vi sagde $\rightsquigarrow x$ om os selv. Kristian var kraftigere end jeg; men jeg vovede en lille udfordring, der lød sådan: $»$ Æ tøs' do snakke som om do hae' katøfle i $x$ mund! * - Sxtningen gav reaktion, Kristian drejede sig om på siden og sagde på bredt jysk: »No vil a te å souv, for a togges, te do er en pjatrøw! « - Det var ord nok. Jeg foretrak nu tavshedens guld for talens sølv. Jeg var blevet 6 år januar 1910, så tiden nærmede sig, at jeg skulle i skole. I god tid blev der sørget for, at jeg fik en tornyster, en tavle og en "griffelkasten «, som vi sagde dengang. Tingene anbragtes foran min seng, så jeg kunne se på dem både morgen og aften. Egentlig glædede jeg mig ikke til dagen, og den viste sig da også som noget 
meget besværligt - især med sproget. Lærerinden spurgte os nykomlinger: "Was ist ein Kopf? * Vi blev spurgt én for én, de fleste måbede bare, indtil spørgsmålet blev stillet til en stor pige Gertrut Mahn, datter af en dygtig tilflyttet tysker, som havde en gård over for skolen. Gertrut Mahn var, selv om hun også kun var 6 år, mere udviklet end vi drenge, som piger tit er, hun var kvik og havde allerede kvindelig charme. Jeg følte mig underlegen, men havde dog mod til for mig selv at synes, at hun var køn. For hende var spørgsmålet lidt irriterende og for let, da de jo havde tysk hussprog hjemme. Hun svarede rapt: "Ein Kopf ist ein Kopf! « Det var da ikke noget at spekulere over. Jeg tænkte på, hvad Kopf kunne være, og en almindelig kop var det, lyden bedst kunne tænkes at passe på; men jeg var ikke sikker, så svaret for mit vedkommende har nok været den almindelige måben.

Til Brunde skole var der $31 / 2 \mathrm{~km}$. Der var skoleleder Holm, en andenlærer Kahlke, der var en god og elskelig mand, og så lærerinden, en satan, der fik tildelt os de små. Hun udleverede en bibel og en katekismus, og vi kom ret hurtigt til at terpe: "Das erste Gebot: Ich bin der Herr dein Gott, Du darfst nicht andere Götter haben neben mir!

"Was ist das? Das ist« o.s.v. Vi skulle læse på det hjemme; men mine forxldre var ikke interesserede $i$, at jeg skulle lære alt det tyske, så da jeg hjemme ikke blev opfordret til at lase lektierne, blev tornysteren med bøgerne stående $\mathrm{i}$ forstuen til nxste dag, og Troels tog som den ellers ordentlige dreng, han var, den daglige blårødstribede sweater på og gik ud og legede. Lærerinden kunne ikke et ord dansk, jeg vil kalde hende en dydig tysk militxrsportslig pige. Hun stod foran katederet og afgav sine korte og bestemte ordrer med en energi, så det gibbede $\mathrm{i}$ hendes underliv for hver kommando, der lød ud i rummet: "Tafel her - eins « (fat i tavlen under bordet) *Zwei!« (tavlen op $\mathrm{i}$ vandret stilling foran næsen) "drei! (tavlen ned på bordet). Hvis sidste kommando ikke blev udført aldeles lydløst, lød det barskt: "Noch einmal - von vorne! « og så igen *Tafel her - eins" o.s.v.

Mit forhold til damen blev mere og mere uforsonligt. Hun tog mig $\mathrm{i}$ øreflippen og drejede rundt, så jeg skreg, og min søster Karen kunne høre det helt oppe $\mathrm{i}$ den næste "Stufe» ved væggen. Måske skulle jeg knægtes, fordi vi var danske hjemme. Jeg drømte om det 
forhadte menneske om natten og havde hallucinationer om dagen. Jeg måtte vel blive stor engang, og jeg forestillede mig selv stor og stxrk, og i den tilstand skulle jeg møde hende, det slemme væsen, hun på cykel, og det skulle være en let sag for mig at vælte hende, og så skulle hun få alle de tærsk, jeg kunne orke, så jeg udmattet og veltilfreds kunne sige hende tak for sidst! Mine forestillinger er aldrig gået $i$ opfyldelse, men tankerne gav mig en form for trøst i min håblose situation.

Efter genforeningen har jeg set småbørnsundervisning, som den skal foregå, og de børn, der blev undervist, så ud til at opfatte hele undervisningen som en leg.

Den periode, jeg gik i Brunde skole, varede i to år, fra 1. maj 1910 til foråret 1912. Der indtraf en bedring, som kom fra en helt uventet kant, i forholdet til lærerinden. Vor pige, Anna Bojsen, vidste noget om min situation, og en aften far og mor ikke var hjemme, satte hun mig til lektiebordet. Opgaven til i morgen var det andet bud, hvis begyndelse lød sådan: „Du darfst nicht fluchen, schwören, zaubern, lügen oder trügen!« Jeg ville ud, græd over det, og syntes den gotiske frakturskrift i den fordømte katekismus var hæslig; men Anna Bojsen holdt mig til bogen, og jeg græd og snøftede indimellem, mens jeg fremstammede alle udsagnsordene, som endte med lïgen oder trügen. Far og mor var jo ikke hjemme, og jeg troede, Anna og jeg var ene $i$ huset; men pludselig rejste karlene sig i stuen ved siden af, hvor de hvilede og holdt aftenro, og mens de gik ud af døren og ned ad trappen for at gå $i$ seng ovre $i$ karlekammeret, fremsagde de med efterlignende tone og snøften mine tvangsord: $\gg D u$ darfst nicht fluchen, schwören, zaubern, lügen oder trügen.« Jeg følte mig beluret og forsmædet; men søvnen lukkede af for min anstrengte bevidsthed.

Næste formiddag i skolen oprandt timen for min store oprejsning. Da lærerinden hørte mig i Luthers Katekismus, sagde jeg alle ordene fra fluchen til trügen uden at stamme. Frokenen blev pludselig forandret, $o g$ i sin iver for at belønne mig, rykkede hun tre drenge ned, og jeg flyttede de tre pladser op oven for dem. I pausen efter timen søgte de at dulme deres depression over det skete ved at sige: "Ham skal vi nu snart få rykket ned igen! « Det skete nu ikke. Jeg havde lært så meget af tildragelsen, at jeg for fremtiden gjorde min pligt og endda var energisk med at lære lektierne. Mit forhold til den nidkære lille tyske dame med den lyse bluse og det morke skørt blev aldrig 
hjerteligt. Hun var opvokset $i$, og kun optaget af, det store rige, som havde "Der Kaiser" til topfigur, og rigets mægtige vilje var hun lydig til at undergive sig.

Brunde skole forlod jeg uden vemod i foråret 1912, og det var store forandringer og påvirkninger, jeg blev udsat for, da vi flyttede til Åbenrå, og min bror og jeg blev sat i Bürgerschule, hvis store bygninger ligger mellem Storegade og Nygade.

For vi rejste fra Skovgård, havde den tyske hærledelse en stor kejsermanøvre. Skovgård fik indkvartering af 150 mand, som kom og skulle bespises lordag eftermiddag. Far lavede et langt bord i den store lade af vognbunde sat på tønder i forlængelse af hinanden. Til sæder blev lagt halmknipper langs siderne. Soldaterne kom sultne og udmattede til Skovgård hen på eftermiddagen. De satte sig til bords, far kom slabende med en balje med en sammenkogt ret fremstillet $i$ gruekedlen $i$ vaskerummet. Et par af befalingsmændene udbrød: „Helf doch den armen Bauern «, hvorefter soldaterne hjalp den arme bonde med baljen. De spiste godt, og da de var færdige, væltede de sig bagover $\mathrm{i}$ halmen og sov til næste morgen. Vi børn fik afskudte patronhylstre af dem, 5 stk. på en skinne, så vi kunne fløjte i dem.

Far og mor var ikke meget selskabelige, da de boede på Skovgård; men der kom alligevel i embeds medfør en del mennesker. Far var blevet landbrugskandidat $i$ april 1898. 1. maj 1900 begyndte han som Nordslesvigs dengang første og eneste konsulent $i$ landbrug og mejeribrug. Jeg har kun hørt far bande 3 eller 4 gange, den ene gang var endda kun på anden hånd, det var, da han første gang så min mor hos H. P. Hanssens på Hejmdal. Efter deres første møde skal far, ifølge Nic. Svendsens udsagn, have sagt, whun er sgu køn «. Far kom i de år tit hos H. P. Hanssens, og mor, der var hjemmehørende i Kolding, havde hørt Hanssen tale ved et møde der, hvorved hun var blevet så begejstret for ham, så hun tog plads hos ham, først et år i huset, og bagefter sad hun på Hejmdals kontor.

Far drillede sommetider mor med, at hun ikke var for god til regning. Han sagde: »Lille mor, hvordan har du kunnet klare det $i$ et helt år på bladkontoret, med den frerdighed du har til at behandle tal?« Mor var nok ikke blevet der så længe, hvis hun ikke havde haft god forstand på det skrevne ord, og så havde hun en så nydelig, ja, en ligefrem flot håndskrift, som vi alle misundte hende. I de pladser jeg har haft, sagde mine foresatte, når der var brev til mig hjemme- 
fra: »Nå Troels, der er nok brev fra din mor, det kan vi se på den flotte håndskrift $\ll$.

Fra Skovgård kom vi tit til Ảbenrå og of te ind på Hejmdals kontor og trykkeri. Der var støjende og indviklede maskiner, og inde $\mathrm{i}$ alt maskineriet kunne man se arme af jern, der greb om typerne, der så ud til at være af bly, og typerne blev sat på plads, så avisen blev laselig. Ude i bagbygningen sad der en pukkelrygget mand, som hed Køcks, han sad $i$ et snævert kontor, med en ligeså snæver hønsegård udenfor. Den vanføre mand var vist meget betroet. Far og mor snakkede meget med ham, både om bladet, de sidste nyheder og om, hvor meget der måtte offentliggøres af hensyn til censuren. Det var næsten som at få et hemmeligt blik ud i den store verden.

Mest festligt var det for os børn, når $H$. P., som vi kaldte ham, var hjemme fra rigsdagen i Berlin. Han var en afgjort børneven. $\mathrm{Vi}$ oplevede det sxrligt, når vi var bedt til julegilde sammen med andre børn, og Bjørn og Ruth, dem af deres egne børn, der var os mest jævnaldrende. Der skulle danses om juletræet. $H$. P. førte an, og vi gjorde store øjne, når han sang højt »Nu har vi jul igen « og $\mathrm{i}$ takt sprang, med samlede ben, næsten en meter højt. Det var meget inciterende, så vi var nødt til at springe med. Bagefter blev vi fordelt ved forskellige borde til spil om pebernødder og gevinster, gerne ting, som H. P. havde haft med fra Berlin. Der var $i$ huset en hjemlig tryghedsfølelse, som næsten ikke fandtes bedre hjemme.

Den samme var til stede på Højtoft, $H$. P. Hanssens sommerbolig på sydsiden af Åbenrå fjord ved siden af Eliselund Badehotel, hvor der var anløbsbro for fjordbådene. Grunden skrånede stxrkt op til Højtoft, så der var mange trapper at gå op ad; men når man først var deroppe, viste der sig en storslået udsigt over den brede fjord med byen Åbenrå inde $\mathrm{i}$ bunden og skove og bakker synskredsen rundt. For os børn gjaldt det om, hvem der bedst kunne trimle, eller slå koldbøtter i græsset ned ad den stejle skrænt. Var det regnvejr, kunne leret på gangene kravle helt op af siderne på fodtøjet, og så var renselsesprocessen tit meget omfattende. Men vi er endnu ikke færdige med Skovgård.

Der blev talt om, at Kloppenborg-Skrumsager skulle komme en eftermiddag. Alene navnet lod ane, at der fulgte volumen med personen, og så stod Kloppenborg foran hoveddøren, stor og stout og mægtig. I godt lune svingede han den store hånd ud, og begyndte en 


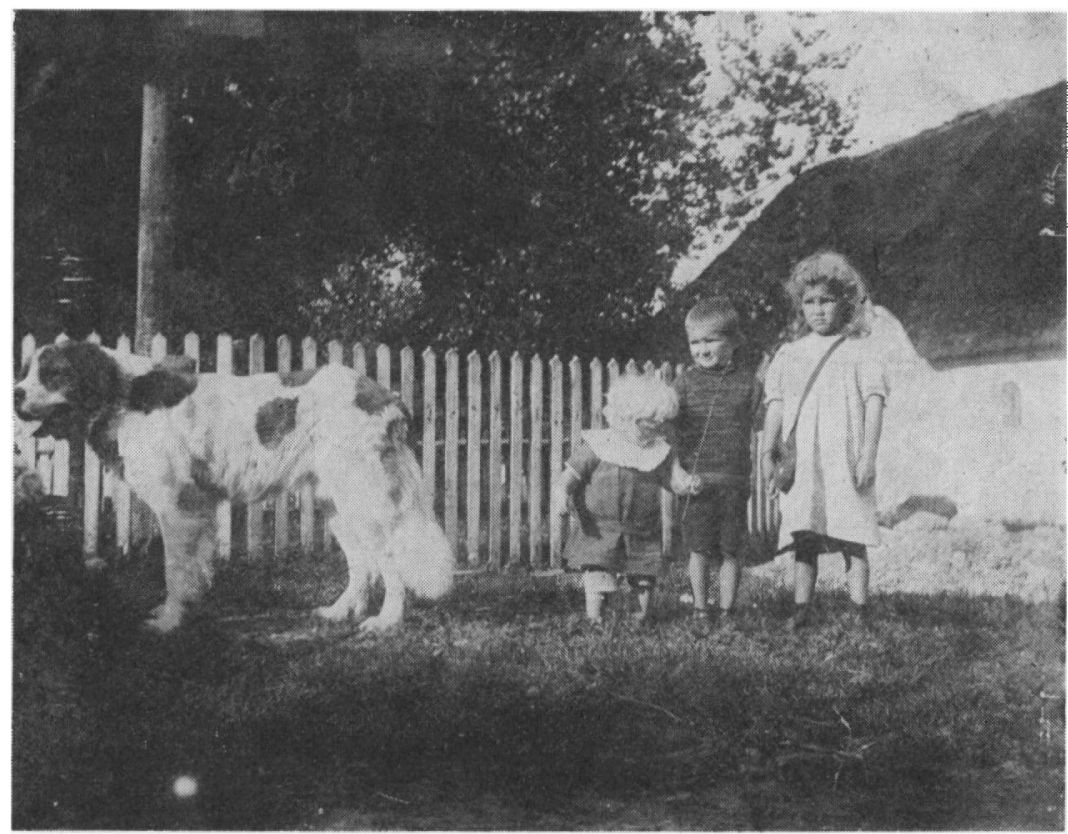

Hunden Rolf, Bunde, Troels og Karen Refslund Poulsen på Skovgard.

anerkendende sætning om gården. I det samme var en forbiflyvende gråspurv så respektløs at tabe en klat, der blev liggende på Kloppenborgs udstrakte hånd. Kloppenborgs tale stoppede brat, og så udbrød han: «Det var da pokkers til ubeskeden fowwl! « Vi børn, der på det tidspunkt ikke vidste, hvor stor gavn Kloppenborgs tale og skikkelse havde gjort for Nordslesvigs sag i den tyske landdag, syntes bare, han var stor og vigtig, og den fugleskid havde han såmænd kun godt af. En anden dag kom en mand, som far snakkede meget med. Han blev til aftensmad, og ved mørkningstid gik far og manden ud til den sære tingest af et køretøj, som manden var kommen $i$. Det er vist den første bil, jeg har set. Der blev foretaget et eller andet ved bilen. Lidt efter begyndte der at løbe vand ud af den. Storesøster Karen bøjede sig over imod os to mindreårige drenge og hviskede: "Den tisser!« De må jo have foretaget modforholdsregler mod frosten.

Manden har sikkert været gårdejer I. H. Schmidt, Vojensgård, der var fars læremester og ven. I. H. Schmidt var den fødte fører $\mathrm{i}$ jordkampen, der var begyndt i 1896 med de tyske domæneopkøb. 
Far frasagde sig sine tillidshverv $\mathrm{i}$ landboforeningen og andet $\mathrm{i}$ 1910 for at blive forretningsfører i den nylig oprettede Nordslesvigsk Kreditforening, der blev en grundpille $i$ jordkampen på dansk side. Fars arbejdsindsats blev mere og mere udadvendt. Karen sagde en dag: $\gg$ Nu har jeg ikke set far $\mathrm{i}$ over 8 dage! « Når vi, i tilbørlig god tid, var kommet $i$ seng, kunne vi høre far snakke $i$ timevis $i$ telefonen, der var ophængt ude i den kolde forstue.

$\mathrm{Da}$ far havde uheld med svin og køer, og Skovgårds jorder heller ikke var givtige, solgte far Skovgård til Heinrich Lawaetz fra Ulkebøl. Far havde skaffet sig oplysning om, at Lawaetz var en dansk mand. Vi var alle kede af, at tærningerne nu var kastede m.h.t. Skovgård, som vi regnede for vort faste hjem. Nu var alting jo uvist med, hvordan fremtiden ville forme sig. Far havde lejet et hus $i$ Åbenrå, Frydendal nr. 3, og da tiden 1. april 1912 nærmede sig, begyndte karlene at tømme stuehuset på Skovgård og køre møblerne ned til Ảbenrå. Vi havde endnu ikke set huset; men vi hørte far snakke med karlene om, at skabe og andet, som ikke kunne tåle regn, hellere måtte stilles indenfor. Den 1. april hen på eftermiddagen var mor ved at smøre noget smørrebrød, som vi kunne tage med derned. Stemningen var mat, og Karen hviskede til mig: "Se mor grxder!«

Hvert enkelt år på Skovgård står for mig i erindringen som et hjul, der langsomt går rundt, som et fikspunkt ved siden stod juletræet som en spids lysende søjle. Hjulet længst tilbage var det største, hjulene derefter blev mindre og mindre; men juletræet var stadig det faste punkt, hvorfra man kunne beregne, at et år var gået. Forestillingen om det største hjul bagved og mindre hjul lxngere fremme, må vel hidrøre fra, at tiden tilsyneladende går hurtigere, jo xldre man bliver.

\section{Abenrå}

Da vi ved flytningen til Åbenrå kom indenfor $\mathrm{i}$ huset, var det skumring. Der blev redt op til os på gulvet mellem de tilfældigt stående mobler i stuen, hvis vægge var mørkebrun oliemalede forneden, en smal fremspringende træliste midt på væggen skilte denne farve fra en lidt lysere foroven. Det var lidt dystert; men søvnen indfandt sig hurtigt, efter at stearinlyset var blæst ud. Menneskets tilpasningsevne er ofte større, end man tror. Vi vannede os hurtigt til de nye forhold. 
Vejen til skolen gik forbi Folkehjem. Næste store bygning havde en mægtig søjle på hver side af indgangen, hvorover der stod: Amtsgericht. Det prangende ved denne bygning skulle vist symbolisere, at bag retsplejen stod der også magt. Facaden til bygningen blev sprængt under 2. verdenskrig, og der er nu en almindelig indgang. Min årgang var delt $\mathrm{i}$ to parallelklasser. Læreren syntes jeg straks godt om, modsat min entré med lærerinden i Brunde skole. Jeg havde diktathæftet med hjem. Blandt andre sætninger havde vi også fåt dikteret: »Unser Lehrer heisst Clausen«. Så vidste jeg da, hvad han hed! Lærer Clausen boede privat $\mathrm{i}$ et højt hus på østsiden af indgangen til Folkehjem. Huset er nu nedrevet og fjernet sammen med bakken, det var bygget på, det skete i 1973, for at den smukke plads foran Folkehjem kunne skabes.

Lxrer Clausen fik jeg straks et godt forhold til. Jeg blev glad for ham, og glad for, at jeg ikke havde fået lærer Krieger, der var lærer for parallelklassen. At lærer Clausen havde et godt øje til mig, fik vi senere, den 17. november 1918, forklaringen på. Da det store historiske møde på Folkehjem blev holdt, hvor H. P. Hanssen talte, forst indenfor $i$ salen og bagefter til den store forsamling udenfor, hvor han forkyndte, at en genforening var i sigte, da lindede lærer Clausen vinduet ovre $i$ sit hus, for at høre, hvad der blev sagt, han var altså dansksindet. Lxrer Clausen gav mig et tillidshverv, det var at tage klassens stilebøger med til skole, når jeg alligevel gik forbi hans hjem. Første gang jeg gik op ad trappen til hans hus, kom Clausen med begge hænder om stilehæfterne. $\mathrm{Da}$ jeg ville tage dem, holdt han ved, og da jeg så spørgende på ham, klappede han mig pludselig på skulderen og sagde: "Du bist treu, mein Junge!« Clausens søn, Karl Clausen, blev sanghistoriker og komponist. Han påbegyndte et sanghistorisk arkiv ved Århus universitet.

Det var god undervisning, vi fik i Apenrader Bürgerschule. Religionsundervisningen ledsagedes tit af salmer fra reformationstiden, »Ein' feste Burg ist unser Gott«, "Lobet den Herrn «, » Nun danket alle Gott « o.s.v. Når jeg nu hører de samme melodier i vor danske kirke, får jeg altid stemningen igen fra den tyske religionsundervisning. Lærerne fortalte meget udførligt om Luther og hans levnedsløb og om modsætningen mellem ham og den katolske kirke. Sxrligt blev fremhævet Luthers kamp mod afladsvæsenet, og afladskræmmeren Tetzel med verset: 
Når pengene i kisten klinger,

straks sjælen ud af skærsilden springer.

Det var naturligt, at tyskerne var stolte af Luther, og at de betragtede ham som en national helligdom.

Skulle vi have gymnastik, Turnen, foregik det nede »o $x$ ma-aj. «

Der var et stort træhus med to tårne på hvert af de forreste hjørner, midt imellem stod med store bogstaver: Städtische Turnhalle.

Systemet, hvorefter gymnastikken foregik, var udarbejdet af Turnvater Jahn. Tyske drenge skulle hærdes; derfor blev der lagt særlig vægt på, at vi skulle kunne klare os i Schlagball, et spil med en stenhård bold, som vi skulle ramme hinanden med. Jeg er ikke hårdfør, så jeg har tudet nogle gange, når jeg blev ramt med den stenhårde bold.

Med sommeren nærmede tidspunktet for Knivsbjergfesten sig. Skolen glædede sig så småt, og læreren viste os ting, som skulle udsættes som belønninger for sportslige præstationer og konkurrencer. $\mathrm{Da}$ jeg en dag fortalte far derom, fik han en lidt alvorlig mine på og sagde afvisende: »Det bliver der ikke noget af, I skal blive hjemme! « I første omgang følte jeg lidt skuffelse, men behøvede dog ingen forklaring for fars beslutsomhed. Det var jo en rigtig tyskerfest, og så måtte far vel kunne bestemme for os, at vi ikke skulle med.

Næste morgen tidlig ved skoledagens begyndelse blev min bror og jeg kaldt op i lærerværelset øverst oppe i skolebygningen. Hele lærerpersonalet var samlet med dystre miner, som om de skulle være med til at opklare et mord. Rektor gik frem imod mig, der var den $x$ ldste, og spurgte med gravalvorlig røst, mens lærerne var musestille, hvorfor vi ikke var kommet til Knivsbjergfesten, som vi alle havde forberedt os til med så store forventninger. Jeg følte mig meget ilde berørt og stammede vist noget om, at far havde holdt os hjemme. Der blev nu røre og sagte talen mellem alle lærerne. Efter nogen tid kom rektor igen hen mod forbryderen, han løftede fingeren truende ad mig og sagde med pathos: „Diesmal geht's, nächstesmal geht's aber nicht mehr! Naste sommer turde far ikke igen holde os hjemme fra Knivsbjergfesten, så vi var med, men til liden moro for min bror og mig, for $\mathrm{da}$ vi satte os og spiste vor mad i græsset, blev vi omringet af hvide tyske marinere og tyske skolebørn, der alle generede os med plattyske tilråb: "Was sind das für ein Paar, seid Ihr Danskes? «

På toppen af Knivsbjerg var et granittårn, $45 \mathrm{~m}$ højt. På en afsats 
oppe på østsiden stod "himself «, Bismarck, i overnaturlig størrelse og skuede med sit prøjserhovede ud over egnen. Senere, i 1919, da jorden begyndte at gynge under ham, skulle han bjerges. Jeg husker endnu nogle af Hejmdals sarkastiske bemærkninger $i$ den anledning. De lød, frit efter hukommelsen, således: Man boltede ham af og lagde ham på langs $i$ en kleinbanegodsvogn, hvor han lå $i$ et par dage på »castrum doloris«. Derefter kom et lokomotiv, der gav et ryk i vognen, så den kom i gang, og Bismarck nikkede et par gange med sit hovede, før han forsvandt sydpå, hvor han vitterligt hører hjemme! Og jeg føjer til: Gid han aldrig kommer her mere!

Gaden Frydendal, hvor vi boede, fører, når man følger Haderslevvej mod nord, skråt ud til venstre. På det spidse hjørne til højre ligger kaptajn Neumanns villa i stil à la Wartburg med tårn. Til venstre over for nr. 3 lå vort almindelige hus. I næste bygning på samme side til venstre boede Wachtmeister Chmella, en jovial mand fra Østpreussen. Han var katolik og havde børnetække, skønt han så frygtindgydende ud, når han red ud på inspektion i fuld uniform med pikkelhue og sabel. Hans søn, Erwin, lidt naiv og godtroende, gik i realskolen. Karl Clausen, der var hans skolekammerat, har fortalt følgende om Erwin: Hvert år, når der skulle rykkes en klasse op, forlangte skoledirektionen, at eleverne skulle registreres helt forfra med Geburtstag, Geburtsort o.s.v. Erwin var led ved altid under spørgsmålet religion at skulle være eneste katolik, og det var også et ømt punkt ved hans modtagelighed for drillerier. Erwin var nu ikke så tosset endda, han fandt på ord til rubrikken, som dxkkede spørgsmålet, og samtidig gjorde drillerier næsten umulige. Han skrev nemlig: Katolisch geboren. Evangelisch erzogen.

En anden dreng, der var skibskaptajnssøn, hvis far og mor havde sejlet på langtur, da han blev født, skrev under Geburtsort: $135^{\circ} 10^{\prime}$ V. $-20^{\circ} 15^{\prime} \mathrm{N}$. Det var ikke alle lærere, der vidste, at den position var et sted i Stillehavet.

Naste nabo til højre var den tyske kaptajn Rasmussen. Han sejlede, var sjældent hjemme. Der var tre børn: Elna, Jürgen og Dedi. De fire nabobørn var vore legekammerater, og legen gik altid på tysk, så den sidste tid af Ảbenråtiden måtte jeg sommetider gribe mig $\mathrm{i}$, at jeg også tænkte på tysk. Mit forhold til tysk er som de gamle latinskoledrenges: Når de blev ældre, ville de gerne tale latin og følte måske en vis foryngelse derved, selv om latinen for dem i skoletiden 


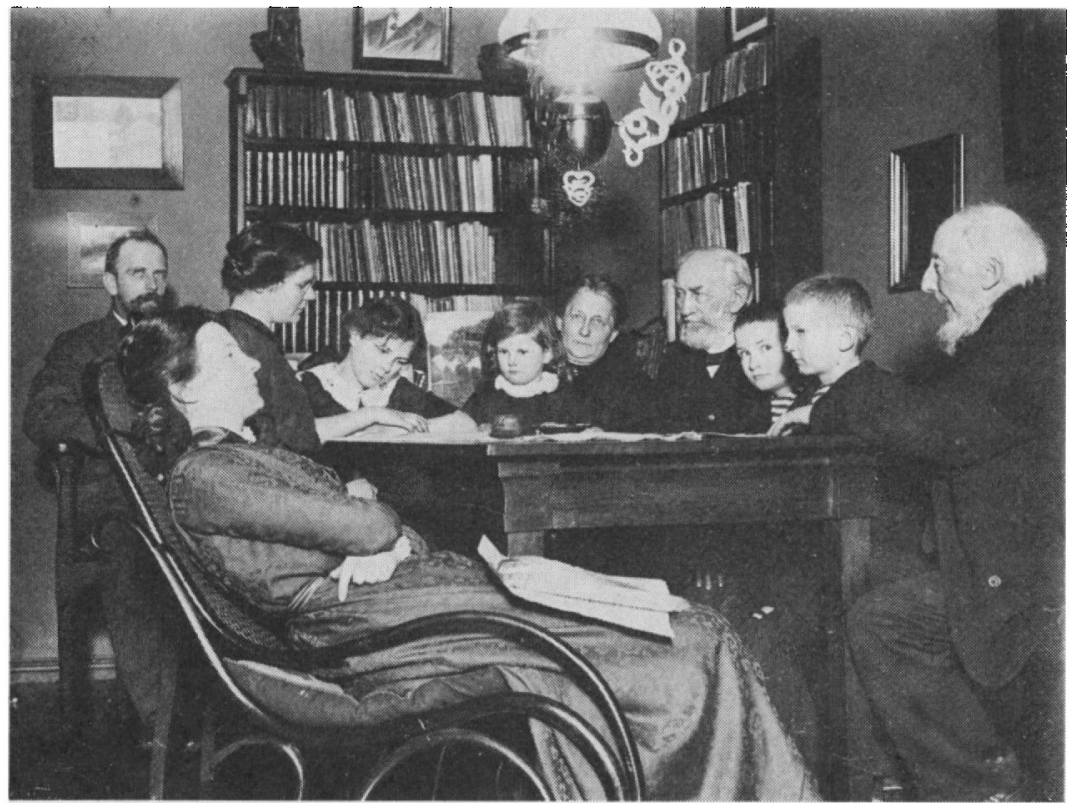

Familiebillede fra Frydendal $3 i$ Abenra 1913. Fra venstre forfatterens foraldre Marten og Marie Refslund Poulsen, Margrethe Christensen, Karen og Else R. P., morforeldrene Henriette og Moritz Jessen, Troels og Bunde R. P. samt deres oldefar, produkthandler Brodersen, Abenrå.

føltes som en forbandelse. Tysk tale har vel nok flere nuancer og muligheder for at »træffe helt på et strå «; men for mig er det blevet en kuriositet, som jeg, da jeg har lært det nogenlunde, gerne vil brillere med. Far og mor talte kun dårligt tysk, mormor derimod meget godt. Hun gjorde mig bl. a. opmærksom på, at man på tysk ikke siger »ein und ein halb «, men »anderthalb«.

Kaptajn Rasmussens kone døde, mens vi en gang var på sommerferie i Bovlund, og Rasmussen giftede sig igen med en dansk dame. Det havde til følge, at familien blev mere danskvendt. Elna er nu gift og bosat i Norge. Elna var en mørkeblond skønhed. En dag, hun gik ad Storegade mellem andre vejfarende, blev hun ramt på kinden af en fast snebold, kastet af en stor fræk dreng. I mit sind, som måske også $\mathrm{i}$ andre vejfarendes, droges hævneren med kujonen om at tage affære eller ej; men fornuften sagde, at der kunne være udsigt til klø, 
da drengen var storre af vækst. Så der blev ikke andet tilbage end en dårlig samvittighed over ikke at have hjulpet eller hrvnet Elna.

Jürgen og Dedi kom på danske læreanstalter. Jürgen tog en tid efter afgangseksamen fra Sorø Akademi.

Næste nabo til højre var den gamle tyske digter, lærer Dresen, der i 1890 digtede sangen om Åbenrå, den lyder således:

Mein Apenrade mit Wald umkränzt wo am Gestade die Ostsee glänzt im Morgenschimmer wie lauter Gold dich lieb ich immer, dir bleib ich hold!

Auf deinen Feldern, wo Blumen blüh'n, in deinen Wäldern, wo Buchen grün, da spielt ich munter am Quell und Bach, bergauf, bergunter so manchen Tag.

Da weilt' ich gerne, war frei und froh, ach, in der Ferne ist's nimmer so, nur süss in Träumen verweil' ich dort in deinen Räumen, lieb Heimatsort.

Bürgerschule - eller »æ burreskol« som den blev kaldt på Ảbenrådialekt - havde i 1913 sin sommerudflugt til Lyksborg. Skolens storre drenge, 190 ialt, blev opstillet på legepladsen i geled på 4 og 4. Foran spillede et orkester Schleswig-Holstein stammverwandt, og så gik det $\mathrm{i}$ march ned til havnen og ombord pa fjordrederiets damper Habicht. Far har fortalt, at fjordrederiets kapital var halvt af tysk og halvt af dansk oprindelse, så damperne fik efter aftale skiftevis danske og tyske navne. Fjorddampernes skønne ture ophørte, da konkurrencen med motorkøretøjerne gjorde det umuligt for dem at sejle med fortjeneste. På udflugtsdagen var Habicht chartret af skolen. Den sejlede os ud af fjorden og ned gennem Alssund, lærer Clausen viste os et mindesmerke i land på Alssiden, et slags kors ved Arnkilsøre, hvor tyskerne var gået over Alssund i krigen 1864.

Alssund snævrede til sydpå, og vi så de store marinebygninger til venstre som en begyndelse af Sønderborg. Pontonbroen lå som en tynd fleksibel pølse lavt over vandet. Da vi nærmede os, var det som 
om den knækkede et sted på midten, og den yderste ende af den del af broen, der hang fast ved Sundevedssiden, svingede ud til syd, som om den ville hilse på os, og samtidig vise os vej videre. Habichts maskineri nede under vandlinien bumpede trofast videre, og vi sejlede sydpå, syd om Broagerhalvøen ind i Flensborg Fjord og lagde til ved dampskibsbroen i syd ud for Lyksborg. De to $\mathrm{km}$ til Lyksborg by gik vi og fortærede vores madpakke der, derefter stillede vi igen op 4 og 4 og marcherede under musikledsagelse rundt om den kønne slotssø med slottet, der rager lige op af vandet midt i. Hjemturen sluttede af på samme måde som begyndelsen med march fra havnen i Åbenrå og til skolepladsen, hvor musikken for sidste gang spillede Schleswig-Holstein meerumschlungen, mens vi skrålede ordene til. Den samme inciterende melodi lød endnu i vore øren, da vi trætte lagde os på puden hjemme efter en god udflugtsdag.

Den sidste gang, jeg sejlede med en af damperne, var omkring året 1930. Da sejlede min far, bror Bunde og jeg fra Åbenrå til Hardeshøj for at deltage i de nationale foreningers årsmøde på Nordborg slots efterskole. Da jeg engang, jeg tror det var i 1957, var i Flensborg og kom til havnen, så jeg til min forbavselse min gamle ven Habicht ligge ved kajen. Det undrede mig, at den stadig var til. Vi havde dog begge siden vort første møde oplevet to verdenskrige, og sluppet tilsyneladende uden skrammer. Et par år efter laste jeg $\mathrm{i}$ avisen, at Habicht $i$ en storm var gået ned $i$ Lübeckerbugten lasset med kreaturer. Stakkels Habicht, vi var dog på en måde "stammverwandte«!

Til mine Åbenråoplevelser hører også, at byen fik luftskibsbesøg. En formiddag lød der skrig og skrål ude på vejen, det var Ảbenråkoner, der havde fået øje på Zeppelineren, de råbte: "Kom ue å se, et luftskiff - nai hvor schaule! «, og så ragede der virkelig et stort uhyre op over hustagene. Motorerne var sat i tomgang, så propellerne nærmest kun hviskede. Menneskene deroppe i den lange gondol gik til vinduerne og vinkede, enkelte lukkede vinduer op og kastede små firkanter, der lignede breve ud. Det hele varede ikke så mange øjeblikke, og tilbage på Frydendalvejen stod Åbenråkonerne og gentog entusiastisk: »Nai - hvo schaule! «. Det tog konerne længere tid at falde til ro igen, end hele forestillingen med luftskibsbesøget havde varet.

Fra 1912-1914, mens vi boede i Åbenrå, havde byen godt 7 tusinde indbyggere, den virkede som en meget tysk by. Det mest domi- 
nerende var naturligvis den tyske øvrighed, og så for mig skolen. Om søndagen hejsede mange af de gode tyske borgere flaget, kejsertidens det sorthvidrøde, egentlig helt pænt. Det kunne dog sommetider genere noget, særligt når stangen med flaget var stukket lavt ud fra et vindue, så det slæbte hen over hovedet, når man gik forbi. Medvirkende til det tyske indtryk var også de mange tyske flådebesøg, som den dybe fjord egnede sig godt til. Pludselig kunne derude langt fra havnen ligge flere store enheder, slagskibe eller krydsere, og når der gaves landlov, myldrede de små landgangsbåde, pinasser, fra kæmperne, der lå derude, urokkelige som grå jernklipper ragende op af vandet. Så vrimlede byen og omegnen af matroser og kadetter i mørkeblå uniformer med den hvidstribede matroskrave. De var altid høflige og velopdragne. Engang vi børn gik tur i Nørreskoven, fattede et par af dem interesse for os. Det var vel nok Karen, den mest voksne, med det pæne ansigt, der tiltrak. De spurgte: Wo mündet die Weichsel? « Karen og vi andre stod bare benovede. De spurgte videre: "Ostsee oder Nordsee? « - stadig tavshed. Så sagde marinerne, idet de gik: »Vielleicht im Schwarzen Meer?!« De var søde; men vi var jo ikke forberedt på eksamination.

Det danske var der jo, men usynligt, eller umærkeligt, indenfor $i$ hjemmene, hvor det havde været siden Arilds tid. Jeg mærkede det stærkt første gang tæt op mod genforeningen. Vi børn var kørt fra Bovlund til Ảbenrå for at være med til modtagelsen af de danske soldater. - I plebiscit-tiden (plebiscit = latin for afstemning) var vi blevet beskyttet, eller besat, af allierede tropper, alpejægere kaldtes nogle af dem. $\mathrm{Da}$ vi havde fået hesten spændt fra, gik vi med små dannebrogsflag på skaft ned til havnen. Vi blev undervejs generet af tyske drenge, der hånligt råbte »dau danske« til os. På havneområdet samledes efterhånden mange folk, med senere amtmand $\mathrm{Kr}$. Refslund Thomsen i spidsen, og vi ventede $i$ timevis. Omsider viste der sig tre fartøjer ud for pynten ved Skarrev. Det var en dansk færgedamper, eskorteret af to danske undervandsbåde, Neptun og Egir. Færgedamperen lagde til kaj, og den krængede lidt over mod bolværket, da mandskabet gik fra borde.

Amtmanden talte med den øverstbefalende for de danske tropper, og »jenserne « stillede op på skibsbroen til det forestående optog gennem byen. Jeg lagde mærke til tyske nysgerrige grupper mellem tilskuerne. De kom med kritiske kommentarer som: "Guck mal, wie sie 
die Gewehre halten! « Og hånende: „Das sind auch Krieger! “ Optoget gik stilfærdigt, uden pomp og pragt, fra havnen op gennem Storegade ad min gamle skolevej, og jeg opdagede vinduer, der blev lukket op, og mennesker stak hovedet ud med tårer ned ad kinderne af bevxgelse over at se danske soldater med Dannebrog foran gå gennem deres by. De aldste af dem havde sikkert sidste gang set danske soldater $\mathrm{i}$ byen morgenen efter hin februarnat, da Danevirke blev rømmet, og soldaterne af udmattelse faldt i søvn på fortovene støttende sig til geværerne. Tårerne, jeg nu så, bevægede mig, og min opfattelse af, at Åbenrå var en tysk by, blev rokket. Jeg anede ikke, at der alligevel var så megen danskhed $\mathrm{i}$ byen.

I Franz v. Jessens Håndbog $\mathrm{i}$ det slesvigske spørgsmåls historie står, at Ảbenrå købstad ved folkeafstemningen 10. febr. 1920 havde $55 \%$ tyske stemmer, deraf var 9,1\% af de afgivne stemmer af personer nordfra, medens $24,6 \%$ af de afgivne stemmer var af personer sydfra. Man kan deraf udlede, at Ảbenrå i realiteten har haft et godt dansk flertal.

Når danskerne kom sammen, var det jo mest på »Folkehjem《. Engang jeg gik fra skole, så jeg far sidde inde på altanen i snak med ligesindede, og jeg har sjælden set far i så godt humør. Far havde fortalt os om Sprogforeningen, den $x$ ldste danske nationale forening, stiftet i 1880 under navnet Foreningen til det danske sprogs bevarelse i Nordslesvig. Det var gode danske mænd og kvinder, der havde startet den, og der var stadig gode folk, der tog sig af den og sørgede for at holde dens bogsamlinger, ca. 200 ialt ud over landsdelen, vedlige. Vi var tit omme i Sprogforeningens lokaler for at låne bøger. Sprogforskeren og digteren Nicolai Andersen var dengang sprogforeningens sekretær, og han og hans kone Sophie var samtidig værtsfolk på Folkehjem. Far og mor var med til et nationalpolitisk kursus der. Det varede i flere dage. Der var også engang en dansk maleriudstilling af forskellige kunstnere i den store sal.

Juletræsfesten i Folkehjems store sal var et klimaks i tilværelsen. Efter at vi børn havde gået om juletræet og sunget og fàet poser, blev træet med danebrogsguirlanderne skubbet hen $i$ et hjørne, og så begyndte de $x$ ldre at danse til musik. Når et musikstykke var holdt op, og gulvet frit, tog vi børn tilløb og rutschede, så langt vi kunne på det glatte gulv. Der var ingen, der hindrede os i det, for musikken igen spillede op. Ude ved væggen sad de, der ikke var så aktive. Far 
sad der engang, jeg hørte lidt af samtalen; der drøftedes, hvad for ord der kunne henregnes til at bande. En af mændene spurgte så: "Hva' så mæ de jæt pinde? *

Åbenrå havde kun de to gamle havnebassiner. I et af dem lå i 1913 endnu et sejlskib, en fuldrigger, og lossede træ. Det var et flot syn med maste, ræer og tove $i$ et bestemt system, sejlene var jo strøgne. Hvor H. P. Hanssensgade nu går, og hvor den nye havn er bygget mod nord, var der dengang en eng, $¥ x$ ma-aj«. Der gives et par dejlige "Sejer" i Åbenrå: "Vil do mæx neen o $x$ ma-aj og plokk en dippeda-aj? « eller *Ve' do mæ ue i e Hjelm skau, å høe $æ$ piffe a e faul? « På stedets dialekt lyder svaret: »Ja tak - det ku' da væe dajlæl «

Engang kom far og mor en dag senere hjem fra besøg i Bovlund, end vi havde ventet. $\mathrm{Vi}$ var alle fire vigtige af, at farfar, frimenighedspræst L. B. Poulsen, whavde» en kirke i Bovlund. Mor så spændt efter vor reaktion, da hun fortalte en stor nyhed: $*$ Vi har købt en gård! « Nyheden vakte ikke straks begejstring, for jeg vil godt spørge: "Hvem kan bo i Ảbenrå i to år, uden at komme til at holde af den?" $\mathrm{Vi}$ kunne i hvert fald ikke; men nu var vor skæbnes terninger igen kastede, og næste flytning var fastsat til 1. april 1914. Skæbnen var måske ved denne flytning alligevel god mod os, for Bovlund var et forholdsvis lunt sted at fjxle sig $i$, da katastrofen for mange mennesker $\mathrm{i}$ verden begyndte fire måneder senere, d. 1. august 1914. 